\title{
A Pedagogical Evaluation of IntRa-Sentential CODE-SWITCHING PATTERNS IN L2 CLASSROOM TALK
}

\author{
JAN MAJER \\ jlmajer@uni.lodz.pl \\ University of Łódź
}

\begin{abstract}
The paper is concerned with teachers' and students' alternation between L1 and L2 within the same utterance, i.e. uses of intra-sentential code-switching which in classroom discourse tends to be less accepted by modern language pedagogy than its inter-sentential counterpart. The rationale for the study is the universal nature of the phenomenon known to occur in the first place in interactions among natural bilinguals and multilinguals. The data analysis sections of the article review eight different patterns which are evaluated pedagogically. It transpires that the category most likely to arouse methodological controversy is code-mixing.
\end{abstract}

Key words: intra-sentential code-switching, language alternation, code-mixing, borrowing, transfer, classroom discourse

\section{Introduction}

This preliminary study is an overview of the typology of intra-sentential L2/L1 alternation and mixing in foreign-language classroom communication viewed from a methodological angle. It is argued that, apart from context-specific features such as the "tutorial" structure of educational discourse, the use of different languages in a pedagogic environment shares certain characteristics of interactions occurring in language-contact situations involving multilingual speakers. Accordingly, bilingual patterns in both teacher talk and learner talk realised as insertional and alternational intra-sentential code-switching - e.g. transfer, borrowing, communication or discourse strategies - are treated here as psycholinguistically motivated hybrid utterances serving different interactional, pragmatic, strategic, as well as pedagogical functions. The material analysed below ranges from sheer lexical gaps of the beginner L2 learner to intentional playful juxtaposition of the two languages by the teacher or the advanced student. Even though foreign language instruction tends to be a bilingual methodology based on concurrent allocation of L1 and L2 rather than their patterned separation, certain types of intra-sentential code-switching are nevertheless observed more frequently, while others can be highly restricted.

The bulk of this paper consists of data analysis based on the author's own observations and a literature review, with pedagogically-oriented commentaries. Because of the varying degree of significance, some patterns have generated more discussion than others. 


\section{Intra-sentential code-switching}

Among the many definitions of code-switching available in the literature, the one by Romaine (1995) seems to reflect the nature of this bilingual or multilingual practice most accurately. The author believes that the phenomenon in question could be conceived as "a continuum ranging from whole-sentences, clauses and other chunks of discourse to single words, which could be inserted into a grammatical structure" (p. 124). This definition appears to cover not just instances of code-switching as "the informal medium of inter-ethnic communication" (Finlayson et al. 1998: 396), but also cases occurring in instructional settings, where L2 is a foreign language for all the parties involved. ${ }^{1}$ In other words, the definition is broader than a sociolinguistic pattern - "a normative way of speaking" where more than one language is used "in a single communicative exchange" (Yau 1997: 41). Furthermore, Romaine's interpretation goes beyond Gumperz's earlier concept of "the juxtaposition within the same speech exchange of passages of speech belonging to two different grammatical systems or subsystems" (1982: 59) in that it does not confine code-switching to inter-sentential alternations.

The adoption of Romaine's continuum does not mean that we consider the otherwise widely recognised formal distinction between inter- and intra-sentential code-switching as an academic issue. Whereas the discussion to follow addresses almost exclusively intra-sentential cases, the reason why we choose to focus primarily on alternations performed on units smaller than a clause is simply practical: a broader treatment of the topic under consideration would clearly go beyond the limits of a short article. ${ }^{2}$ And another reason is pedagogical. It is precisely those types of switches that spark considerable controversy in L2 classroom discourse (cf. Majer 2006). Moore (2002) observes that "a view still commonly shared among L2 teachers is [...] to remain highly suspicious of intra-sentential mixing of the two languages" (p. 280). On the other hand, whole stretches of alternated discourse in L1 and L2 are commonplace in L2 classroom communication. To be sure, this type of language alternation may still come in for criticism, as methodologists and teacher trainers advocate avoiding L1 while maximising input in L2, yet from a sociolinguistic point of view inter-sentential code-switching turns out to be much less controversial in the foreign-language classroom.

\section{Assimilated borrowings}

The first pattern deserves merely to be acknowledged. Uses such as $O K$, frequently observed in both teacher and learner talk e.g. in English classrooms in Poland, are unmarked, and so it would be difficult to determine whether the codes have indeed been switched. Whatever their actual linguistic status, assimilated borrowings do not appear to be a pedagogical issue. We therefore proceed to evaluate further items in the taxonomy.

\footnotetext{
${ }^{1}$ That is, excluding situations where two languages are used for educational or occupational purposes, such as in immersion programmes (e.g. Nussbaum 1991; Bourguignon et al. 1994; Pekarek 1999; Björk-Willén 2008), or where no common language is shared between teachers and pupils, such as in plurilingual classes (e.g. Muller and Baetens Beardsmore 2004).

${ }^{2}$ However, refer to Majer (2009, forthcoming) for a more exhaustive discussion.
} 


\section{Unassimilated borrowings (or interlanguage borrowings)}

The next type of intra-sentential bilingual patterns is much more marked and it tends to attract the attention of the participants of L2 classroom discourse. Termed unassimilated borrowings or interlanguage borrowings (cf. Majer 1983) for contrast, this use consists in L2 phonological and/or morphological ${ }^{3}$ adaptation of a stem transferred from L1. The following example can serve to illustrate the phenomenon in question (own data):

This lays down the fundament-s ${ }^{4}$ for further analysis.

Here an instructed L2 learner attaches the English plural ending to a Polish word which is presumably considered to be "borrowable", i.e. an internationalism. Thus, the lexical base and the morphological ending come from two different sources, like in cases attested in language-contact situations (de Bot 2002). Even though the mechanism responsible for this kind of code-mixing is parallel to the one triggering lexical gaps discussed elsewhere in this paper (see the subsequent section), we need to differentiate between the two instances of borrowing. Whereas the former type could be treated as a communication strategy, in the case of interlanguage borrowings we are clearly dealing with transfer.

Typologically, too, this pattern also compares with the category identified as playful use (see Section 6 below). But the significant difference is the pragmatic function, i.e. lack of speaker intentionality in unassimilated borrowings. Besides, there are important distributional and pedagogical constraints. Playful uses are typically observed in teacher talk and can be considered to be discourse strategies, whereas interlanguage borrowings happen to coincide with lower levels of proficiency in L2.

\section{Lexical gaps}

The fourth type in our analysis of intra-sentential code-switching patterns in L2 classroom communication is represented by what is known in language-contact literature as lexical gaps (Romaine 1995: 66). These occur because learners are often found to quote L1 items which they believe to be translational equivalents of L2 items. This is evidenced in the following confirmation check realised as an intonation question. The transcript is reproduced here with slight modifications after Paprocka-Piotrowska (2008; L1 = French, L2 = Polish).

(2) I pyta pomagać z kolegą, z psą. Psą decyduje pomagać au- kolega. I dodaćdoda- une échelle?

\footnotetext{
${ }^{3}$ Also orthographic (cf. Majer 1983). The present study is not concerned with written data, however.

4 "Foundations".

5 "And he asks a friend for help, his dog. The dog decides to help his- friend. And offer- offers [him]- a ladder?"
} 
Intra-sentential code-switching tends to be triggered under the circumstances when there seem to exist no direct equivalents in the respective lexicons of the two systems. However, as regards the student in example (2), the lexical gap must simply have been filled by way of an attempt to overcome temporary communication difficulties rather than from making use of an option permanently stored in the mental lexicon. In pragmatic terms, we have reason to believe that the above use is a communication strategy. As the learner's intonation question was directed to a native speaker, we could be dealing with a request for assistance or an appeal to authority (cf. Yule and Tarone 1997).

In another example, it is, in turn, the teacher who consciously quotes an L1 element considered culture-specific and thus thought to be virtually untranslatable, unless one wants to use a longer paraphrase or circumlocution (Majer 2003; L1 = Polish):

$$
\text { Of course people are unhappy and they will protest because of this popiwek. }{ }^{6}
$$

A tentative generalisation can be made. Lexical gaps are filled by both L2 learners and non-native teachers for reasons which may be different in terms of interactional or strategic goals, but which nonetheless stem from comparable deficiencies in linguistic resources.

\section{Playful uses}

Another means by which participants of L2 classroom interaction can utilise the resources afforded by the two systems is playful use, also attested in studies of naturalistic bilingualism (Deumert 2004). The intra-sentential pattern in question may not differ formally from some of the other types discussed here, but there is a pragmatically defined intention on the part of the speaker. Chan (2004: 8) is of the opinion that code-switching is motivated by speech acts or propositional attitudes, either signalled overtly or to be inferred by the audience. Deumert $(2004: 125 ; 130)$, in turn, emphasises the function of speaker agency. Going beyond the scope of the present study, the author supposes that not only heavy borrowing but also conscious, deliberate language choice and creative, playful character of switching could be responsible for the development of mixed languages. ${ }^{7}$

However, in order to revert to the pedagogical context of our discussion, let us briefly analyse the following two examples from EFL classrooms - one involving Korean (after Morimoto 1999) and the other Polish as the learners' and the teacher's L1:

$$
\text { Second group. Second group-ul ceyil cohahay. }{ }^{8}
$$

No to musimy ten termin $s$-kancel-ować, ${ }^{9}$ if I may say so - cancel.

\footnotetext{
${ }^{6}$ A pseudo-metaphorical term, based on an acronym, temporarily referred to a kind of surtax used in Poland in the early 1990s.

${ }^{7}$ Cf. Bakker (2003) and Dirim \& Hieronymus (2003) for diverse approaches to mixed languages.

8 "Second group. I like (this) second group best".
} 
Admittedly, the teachers in the respective cases begin their utterance in the opposite codes: in (4) it is L2, whereas in (5) it is L1. Yet in either instance is the borrowed lexical material from L2 elaborated on using L1 morphology. The Korean case marker ($u l)$ and the Polish verb prefix (s-) as well as ending (-ować) are all attached to English free morphemes. If it were not for the playful use, these examples could be assigned to the unassimilated borrowing or code-mixing types.

What might be the discourse function of this type of code-switching? Moore (2002) believes that "a switch to L1, whether initiated by the teacher or the student, is likely to arouse the degree of attention paid to discourse content and/or form, and will usually involve feedback, as well as open a new sequence of negotiation and production in L2" (p. 281). The examples analysed in this section demonstrate that code-switching can function as a communicative tool whose pragmatic and inferential meanings add an extra playful overtone to the meanings expressed in words (Auer 1995).

\section{Flagged switches}

Furthermore, bilingual communication in the L2 classroom can be shaped by instances of what is known in the literature on contact linguistics as flagged switches (cf. MyersScotton 2002), also called nonce loans or single-constituent switches (Romaine 1995). Let us consider a sample of intra-sentential flagged switching from teacher talk recorded by the present writer in a Polish educational setting (6):

$$
\text { Sprawa - jak to się mówi w Anglii - od tygodni zawieszona w limbo. }{ }^{10}
$$

On the one hand, such uses may not differ at all from lexical gaps dealt with previously in this study. On the surface, the mechanism simply consists in borrowing single lexical items from the other system and in incorporating them in utterances expressed almost wholly in the default system. Nevertheless, as exemplified above, flagged switches are preceded by hedging devices which are meant to "warn" the audience, as it were, of the forthcoming nonce use. The phrase jak to się mówi in (6) serves precisely this function.

\section{Trigger-words (or bilingual bridges)}

The next type of discourse in which the two systems can be used together has been identified by relevant studies on language contact as trigger-words (Clyne 1967) or bilingual bridges (McCormick 2003). Intra-sentential switches of this kind can be defined as lexical items that "may facilitate a transversion from one language to another" and that can be identified as belonging to more than one language spoken by an individual or a speech community (Clyne 2003: 162).

The mechanism operating behind bilingual bridges is rather simple. Intra-sentential code-switching occurs at precisely the word that happens to belong in both lexicons in an

\footnotetext{
9 "So we have to cancel that date".

10 "The case - as they say in England - [has been] in limbo for weeks".
} 
almost identical phonological shape. For example, in (7), the Polish teacher of English makes use of a trigger-phrase, public relations, after the occurrence of which the codes are switched:

Jak się robi, wiecie, $w$ public relations, ${ }^{11}$ you've got to be able to respond to public uh tastes.

As evidenced above, it is the lexical item shared by both systems that provokes the switch - a marker of classroom language policy. The category of bilingual bridges is thus motivated by a discourse strategy serving a particular pedagogical goal. Otherwise, phrases such as public relations could be treated as (partly) assimilated borrowings.

\section{Code-mixing}

Code-mixing, also called language switching or "meaningless" language alternation, is yet another way of combining L2 with L1 within the same utterance. In the literature on contact linguistics, it tends to be distinguished from code-switching "proper" since it refers primarily to the intra-sentential level and it involves "the mixing of affixes, words, phrases and clauses from more than one language within the same sentence and speech situation" (Ncoko et al. 2000: 227). It is to this highly controversial category that we devote more space in the discussion.

Superficially, code-mixing appears to resemble the classes dealt with in the preceding sections, namely borrowing. Where the present type does differ is in the psycholinguistic sense. How much consciousness, intentionality and strategic behaviour is actually involved? The intriguing aspect of code-mixing is that, on the face of it, there does not seem to be the sort of pragmatic motivation that underlies switching in playful use, or the semantic need that triggers lexical gaps. As a consequence, the codes may appear to be switched back and forth in the middle of a phrase or sentence for no particular communicative or pedagogical reason. Let us first look at a characteristic exchange involving bilingual learner talk interrupted by the teacher's intervention in L2 (data from Majer 2003):

$$
\begin{aligned}
& \text { S1: (TO S2) Would you like to a single room or- zdaje się, że się mówi }{ }^{12} \text { a } \\
& \text { double, tak? } \\
& \text { S2: Tak. }{ }^{13} \\
& \text { S1: No to }{ }^{14} \text { a double room. } \\
& \text { T: Stop this Polish, you have to practise, boys! }
\end{aligned}
$$

Yet even more typically perhaps, the codes in learner talk are switched at the intersentential level, e.g. (after Eldridge 1996; L1 = Turkish):

\footnotetext{
11 "When you work, you know, in public relations...".

12 "I suppose it's called..., isn't it?"

13 "Yes".

14 "Then [let it be]".
} 
Where did Robert? - ondan sonra? - neydi $?^{15}$

Majer (2003: 407) writes that what distinguishes learners' participation rights from the teacher's duties in a homogeneous, monolingual class is that the provision of the proper linguistic model is expected of teacher talk, not necessarily learner talk. It is therefore paradoxical that teachers who do not tolerate bilingual interlanguage talk should let their own output switch back and forth between L2 and L1. Compare (data from Majer 2006):

A minute na zapisanie tematu. To tylko takie revision. ${ }^{16}$

Admittedly, in the cited utterance which fulfils the instructor's procedural goal, L2 (English) and L1 (Polish) are interchanged freely. From the point of view of language pedagogy, this type of alternation does not appear to serve any specific purpose - either core, or framework, or social goals for that matter. And yet it turns out to be very frequent in L2 classrooms (cf. Majer and Majer 1996), so there must be some more practical objective. As emphasised by Majer (2006),

non-native teachers [tend] to confine their use of L2 to the realisation of core and/or framework goals. In other words, as competent users of L2, those instructors can be said to purposely underperform, thus not only reducing the amount of available input, but also depriving students of opportunities to participate in meaningful exchanges in the target language, not excluding those with a non-pedagogical focus (p. 126).

Not infrequently, however, such teachers insist on learners themselves performing in L2 by encouraging them partly in L1. Compare (Majer 2009):

$$
\text { Ale zaraz, zaraz! In English mi tu proszę! Co jest, girls? }{ }^{17}
$$

The utterance by this Polish instructor of English is constructed almost identically as in the previous example, except that the form seems to somehow clash with the content, while the students are not really given convincing support in their expected effort to sustain interaction in L2 only. This is also the case in extract (10), where L1 is English and L2 is French (adapted slightly from Macaro 2001), except that here the switch is inter-sentential.

\section{And talk only in French. Bon, allez, commencez. ${ }^{18}$}

It also has to be admitted that, in spite of the seemingly "non-significant" character of bilingual talk, in non-educational discourse internal language alternation never affects fillers such as English you know or Spanish de vez en cuando ${ }^{19}$ (Poplack 1980). Interestingly, this is also true of comparable communication patterns in L2 classroom

\footnotetext{
15 "After that - what was it?"

16 "A minute to write down the topic. It's only some sort of revision".

17 "But wait, wait! In English, won't you please! What's going on, girls?"

18 "Good, go, start".

19 "From time to time".
} 
bilingual discourse. Take, for example, (11) - another excerpt collected by the present writer in the course of observations made in typical educational environments (L1 = Polish; L2 = English).

Opowiedz o swoich daily routines. ${ }^{20} \mathrm{O}$ swoich zwyczajach, ${ }^{21}$ habits, you know, takie tam zwykłe rzeczy, ${ }^{22}$ boring stuff.

In the above sample of teacher talk, utterance completion and switching do not necessarily co-occur. Pedagogically, this makes little sense and would not be supported by any methodology employed in language pedagogy. Let us then focus on the sociopragmatic aspects of this type of classroom talk. As pointed out by Majer (2003: 404), in the educational context of the institutionalised status of L2 as a school subject teachers exercise their power, which lets them alternate between the two codes in a manner that they would not be prepared to tolerate in their students' output. Therefore, rather than select the term "code-switching" to cover the case just described, it would perhaps be more appropriate to employ the notion "code-mixing" adopted as the heading of this section.

How can we account for the uses presented in (9), (10) and (11) if they do not appear to serve direct informative or pedagogical purposes? One possibility is to look for universal features of linguistic communication underlying interaction. Thus, McCormick (2003) suggests that the factors immediately responsible are focus on meaning and speaker intentionality. Deumert (2004), too, is of the opinion that the sociolinguistic taxonomy of hybrid utterances does not depend only on the insertional as opposed to alternational patterns within the mixed linguistic constitution of the talk, but "on the way these language choices intentionally modify pragmatic meaning and redefine the social context in which speech occurs" (p. 119). In other words, code-mixing is constrained both formally and situationally.

\section{Pedagogical implications}

Essentially, language policy and language distribution in the classroom remain methodological issues. However, irrespective of the method of instruction, language choice in teacher talk will be perceived by the students as either pedagogical or sociolinguistic acts. As for the students themselves, Üstünel and Seedhouse (2005) believe that through language alternation they can, for example, show their alignment or misalignment with the teacher's pedagogical focus. On the other hand, though, L2 learners are much more restricted in their rights to make full use of the linguistic resources being at their disposal, particularly in the form of code-mixing.

Furthermore, certain intra-sentential patterns turn out to be marked, while others may go virtually unnoticed. For example, cross-linguistic operations performed at morpheme boundaries stand out more than borrowings involving whole lexical items, particularly if

\footnotetext{
20 "Talk about your daily routines".

21 "About your habits".

22 "Some such run-of-the-mill things".
} 
a word search is unproductive, while a translation is not forthcoming. Likewise, codemixing is more likely to be stigmatised than "neat" inter-sentential code alternation.

Finally, our provisional analysis seems to indicate that it is the said intra-sentential codemixing, and not code-switching, that is most likely reported in many studies of bilingual talk in foreign-language classroom interaction. For example, in Eldridge (1996) the use of L1 (Turkish) in what is supposed to be communication in L2 (English) involves young adolescent EFL learners, which is a very typical educational context. For this reason, Eldridge's view that code switching is a natural and purposeful phenomenon which facilitates both communication and learning seems somewhat simplified when it is meant to refer to language teaching. To be sure, it would be difficult to oppose that author's methodological view whereby "decreasing mother tongue use in the classroom does not automatically increase the quality and quantity of target language use, any more than decreasing one's consumption of meat automatically increases one's consumption of cheese" (p. 331). However, on sociolinguistic grounds, code-switching is perhaps too broad a term to apply to the confines of pedagogical discourse. We need to acknowledge that out of the many functions of language alternation recognised in naturalistic bilingual or multilingual discourse only certain ones are shared by L2 classroom interaction. Of those, still fewer would be recommended by methodologists as devices facilitating both classroom communication and instructed learning. Clearly, code-mixing should not be among them - either as regards teacher talk or learner talk.

\section{References}

Auer, P. 1995. The pragmatics of codeswitching: A sequential approach. In L. Milroy and P. Muysken (eds) One Speaker, Two Languages. Cambridge: Cambridge University Press. 115-135.

Bakker, P. 2003. Mixed languages as autonomous systems. In Y. Matras and P. Bakker (eds) The Mixed Language Debate. Theoretical and Empirical Advances. Berlin/New York: Mouton De Gruyter. 107-150.

Björk-Willén, P. 2008. Routine trouble: How preschool children participate in. multilingual instruction. Applied Linguistics $29 / 4$ : 555-577.

Bourguignon, C. H., B. Py and A-M. Ragot. 1994. Recherche sur L'école Maternelle Bilingue en Vallée d'Aoste, Aspects Psycholinguistiques. Aoste: IRRSAE.

Chan, B. 2004. Beyond 'contextualization'. Code-switching as a 'textualization cue'. Journal of Language and Social Psychology 23/1: 7-27.

Clyne, M. 1967. Transference and Triggering. The Hague: Martinus Nijhoff.

Clyne, M. 2003. Dynamics of Language Contact. Cambridge: Cambridge University Press.

de Bot, K. 2002. Cognitive processes in bilinguals: Language choice and codeswitching. In R. Kaplan (ed) The Oxford Handbook of Applied Linguistics. Oxford: Oxford University Press. 287-300.

Deumert, A. 2004. The unbearable lightness of being bilingual: English-Afrikaans language contact in South Africa. Language Sciences 27: 113-135. 
Dirim, İ. and A. Hieronymus. 2003. Cultural orientation and language use among multilingual youth groups: 'For me it is like we all speak one language'. Journal of Multilingual and Multicultural Development 24/1-2: 42-55.

Eldridge, J. 1996. Code-switching in a Turkish secondary school. ELT Journal 50: 303311.

Finlayson, R., K. Calteaux and C. Myers-Scotton. 1998. Orderly mixing and accommodation in South African codeswitching. Journal of Sociolinguistics 2/3: $395-420$.

Gumperz, J. J. 1982. Discourse Strategies. Cambridge: Cambridge University Press.

Macaro, E. 2001. Analysing student teachers' codeswitching in foreign language classrooms: Theories and decision making. The Modern Language Journal 85/4: 531-548.

Majer, H. and J. Majer. 1996. Teacher talk: Theory and classroom realities. In J. Field, A. Graham and M. Peacock (eds) Insights 1. Whitstable, Kent: IATEFL. 13-22.

Majer, J. 1983. A Study of Foreign Language Learners' Lexical Borrowings. Bydgoszcz: Wydawnictwo WSP w Bydgoszczy.

Majer, J. 2003. Interactive Discourse in the Foreign Language Classroom. Łódź: Wydawnictwo Uniwersytetu Łódzkiego.

Majer, J. 2006. Code-switching in classroom talk: A continuing controversy of language pedagogy. In J. Zybert (ed) Issues in Foreign Language Learning and Teaching. Warszawa: Wydawnictwo Uniwersytetu Warszawskiego. 124-146.

Majer, J. 2009 (forthcoming). Code-switching patterns in bilingual communities of practice: A pedagogical perspective. Włocławek: Wydawnictwo PWSZ we Włocławku.

McCormick, K. 2003. Language in Cape Town's District Six. Oxford: Oxford University Press.

Moore, D. 2002. Case study. Code-switching and learning in the classroom. International Journal of Bilingual Education and Bilingualism 5/5: 279-293.

Morimoto, Y. 1999. Making words in two languages: A prosodic account of JapaneseEnglish language mixing. The International Journal of Bilingualism. 3/1: 23-44.

Muller, A. and H. Baetens Beardsmore. 2004. Multilingual interaction in plurilingual classes - European school practice. Journal of Multilingual and Multicultural Development 7/1: 24-42.

Myers-Scotton, C. 2002. Contact Linguistics. Bilingual Encounters and Grammatical Outcomes. Oxford: Oxford University Press.

Ncoko, S. O. S., R. Osman and K. Cockroft. 2000. Codeswitching among multilingual learners in primary schools in South Africa: An exploratory study. International Journal of Bilingual Education and Bilingualism 3/4: 225-241.

Nussbaum, L. 1991. La lengua materna en clase de lengua extranjera: Entre la ayuda y el obstáculo. Signos 4: 36-47.

Paprocka-Piotrowska, U. 2008. Conter au risque de tout changer. Complexité contextuelle et référence aux procès dans l'acquisition du français $L 2$ et du polonais L2. Lublin: Towarzystwo Naukowe KUL.

Pekarek, S. 1999. Stratégies de communication bilingues en classe de L2? Enjeux acquisitionnels et enjeux communicatifs. AILE Numéro Spécial 1999. La Personne Bilingue. Eurosla-CNRS-British Institute-Paris 8. 127-141. 
Poplack, S. 1980. Sometimes I'll start a sentence in English y termino en español: Toward a typology of code-switching. Linguistics 18: 581-616.

Romaine, S. 1995. Bilingualism. Second Edition. Oxford: Blackwell Publishing.

Üstünel, E. and P. Seedhouse. 2005. Why that, in that language, right now? Codeswitching and pedagogical focus. International Journal of Applied Linguistics 15/3: 302-325.

Yau, F. M. 1997. Code switching and language choice in the Hong Kong Legislative Council. Journal of Multilingual and Multicultural Development 18/1: 42-53.

Yule, G. and E. Tarone. 1997. Investigating communication strategies in L2 reference: Pros and cons. In G. Kasper and E. Kellerman (eds), Communication Strategies. Psycholinguistic and Sociolinguistic Perspectives. London: Longman. 17-30. 